\title{
Remote Ancestors or Scientific Evidence? Prehispanic Mummies from the Canary Islands in the Media
}

\author{
María Dolores Meneses Fernández', María García Morales² and \\ Fernando Estévez Gonzálezı
}

\footnotetext{
I Universidad de La Laguna, 3807I La Laguna, Canary Islands, Spain.

2 Organismo Autónomo de Museos y Centros, Conservation Area. 38003 Santa Cruz de Tenerife, Canary Island, Spain.
}

KEY WORDS: mummies, Canary Islands, museum, mass media, journalism, meanings

\section{ABSTRACT}

People have always been fascinated by mummies. In Tenerife (Canary Islands, Spain), the mummified remains of its ancient inhabitants are a source for superstition, fear, respectful recognition, collecting greediness, nationalistic pride, or scientific interest in modern Canarians. This paper discusses the different values and meanings that the cultural industry-mass media included-has bestowed on these mummies. Sensationalist approaches, identity issues, and diversions from the scientific discourse inserted in the news, reports, and opinion articles published in local newspapers and Spanish periodicals are examinedparticularly the influence exerted by the Archaeological Museum by way of scientific publications and press releases regarding the mummies' social and political uses. This paper also analyses how the museum's visitors perceive the displayed mummies and their accompanying messages, in order to track if previous ideas released in the media have influenced them.

\section{Introduction}

Mummies have always produced a great fascination on people, consequently journalists deem them as a valuable informative material about ancient cultures eagerly accepted in the western society. People' interest on mummies has two sources: the sort of scientific evidences that can be retrieved from them and the cultural meanings they embody, which can be singularised and reworked to convey social and ideological constructions. It cannot amaze us thus that the symbolic meanings invested on mummies are generally imposed on any archaeological, anthropological or historical significance. The aims of this research are to determine and analyse: First the importance that the results from research on Canarian mummies has in the journalistic discourse. Second, the influence the Archaeological Museum exerts - via scientific publications and press releases - on the mummies' social and political uses.

Third if the museum' visitors perception of the displayed mummies and the associated narratives are influenced by previous conceptions released in the media.

\section{Research Scope}

The mummies studied are from the aboriginal inhabitants of Tenerife, Canary Islands (Fig. 1).

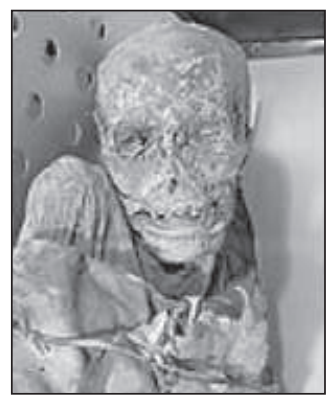

Fig. 1 - Male aboriginal mummy from Tenerife. It is the most shown specimen in the publications and media.

I. These people reached the island in the 9th century BC and developed a particular culture, which came to an end in the $16^{\text {th }}$ century AC.

The mass media examined were publications from the Canaries and abroad and news agencies: daily newspapers covering current news, scientific periodicals and some pseudoscientific magazines. They all have in common to have processed newsworthy facts or curiosities related to the aboriginal mummies. A statistical significant percentage of the museums visitors knew about the mummies in the media, which account for our searching of the news coverage of the mummies made by journalists (Fig. 2). The museum' texts and press releases were also examined.

\section{Methodology}

The hemerographic search was delimited to that news published in two periods: 


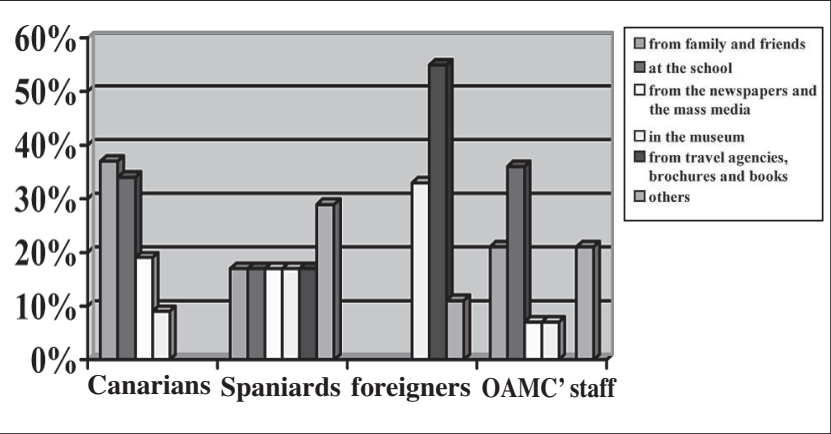

Fig. 2 - Sources from which the museum' visitors learnt about the mummies.

a) From the previous days to the opening of the Ist International Congress on Mummy Studies held in Tenerife in February 1992 to the closure of the exhibition: Mummies. Riddles from the past in March 1992. Both events organized by the Archaeological Museum.

b) 2003. In this year two aboriginal mummies, which were moved to Argentina in the early 19th century were recuperated. This coming back home was sponsored by the nationalist party, which controls the local government. In total one hundred and eighty nine text were analysed: one hundred and sixty were news, reports and interviews; and twenty-nine were editorials.

A tick-in survey was conducted among the museum' visitors to find out their opinion on the mummies and the way they were treated in the museum and the media. In order to contrast the resulting opinions the same survey was conducted among the museum staff.

\section{Research aims}

The contemporary social and cultural dynamic in the Canary Islands is linked to a nationalistic claim of having a distinctive Canary culture rooted in the aboriginal past (Meneses Fernández, M.D., 2004). These claims nurtured by political factions and most intellectuals are sustained in archaeological, ethnographic and anthropological studies and, in particular, in the attempt to catalogue those identity symbols that signify the present Canary culture (Rodrigo Alsina, 1999; Castell, 2003). This task was carried out looking back to a more imagined than real aboriginal past because in a western cultural milieu the oldest is the most valuable and authentic (García Morales, 2003). "Lo nuestro" - our own - is the political-driven term commonly used to signify and synthesize these nationalistic claims.

\section{Research hypothesis}

The mass media mirrors this enhancement of "our own". Our study starts out from the premise that the mummies are the main cultural element, which connects some modern Canary individuals with the aborigines via genetic inheritance (Estévez González, 1987). They are archaeological objects prone to be divested from their original status, reclassified and singularised (García Morales, 2003). As a result the media coverage these mummies can be considered as an indicative of both the excellence/ professional level of the scientific journalism and local journalists in the Canaries.

\section{Results}

The aborigines are identified as "guanche" - the name they were supposed to name themselves - "people" or "race" in the media. These terms indicate the use of a rather subjective journalistic language instead of a more objective one, which uses a more precise terminology like preHispanic inhabitants or aborigines.

The social and cultural complexity of the aboriginal communities is turned into an imagined temporal and cultural homogeneity.

The mass media back the thesis of some social groups, which attempt to associate the aborigines' origins to prestigious ancient cultures such as the Egyptian. It even asserts the survival of the aboriginal race via genetic inheritance.

In general, Canary journalists do not investigate, distrust or differ from the authoritative and political-driven thesis on aboriginal mummies: the most ancient the most valuable and significant. That is why Canary modern origins are tracked down to the aboriginal past.

The late 19th century romantic picture of a honourable aborigine - Rousseau' bon savage - is artificially forced to coexist with a more realistic picture of warlike people without admitting any incongruity between them.

The aborigines are projected to an international scientific level by setting analogies with other ancient western cultures and requesting the opinion of foreign expertises. The journalistic language treats mummies like individuals rather than archaeological objects in contrast to the museum displayed texts and publications. It uses expressions like: Guanche' mummies kidnapped, repatriation of Guanche, the Guanches are individuals or Guanches abroad. The journalists do not meet with informative objectiveness, and get emotionally involved with figurative reconstructions of the aboriginal past, speaking of the mummies as "our ancestors".

The analysed media echoes long-term internal quarrels among the different islands' cultural and political institutions and groups.

The survey conducted among the museum's visitors and its staff produced some unexpected results like most Canaries visitors did not perceived any ideological-driven use of the mummies by nationalistic factions. However the hypothesis that the local visitors believed there is a Canary culture rooted in the aboriginal past was confirmed (Fig. 3). This visitors' certainty about the origins of the Canaries culture contrasts with the opinions of the museum' staff much more critical with the authoritative discourse they produce and divulge. 


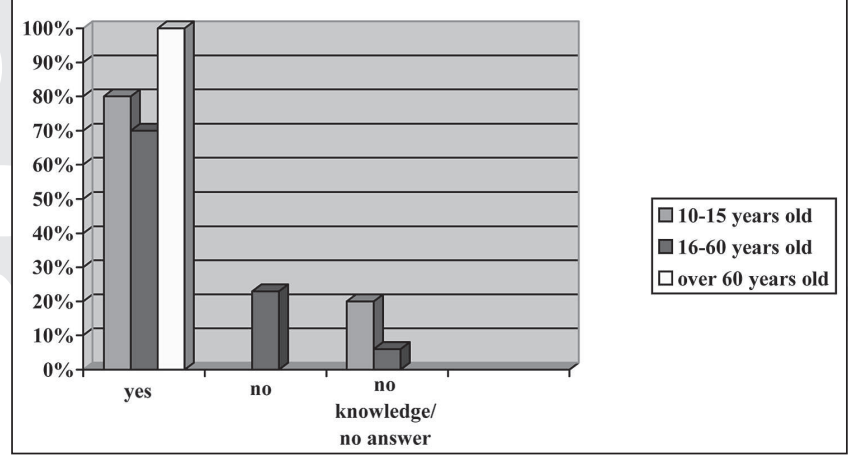

Fig. 3 - Canaries visitors' perception of their cultural origins.

\section{Conclusions}

The results of our analysis show that the Canary media have manipulated the information on mummies to convey other meanings than those rigorously based on scientific evidences. This manipulation is to a certain extent a consequence of the journalists' inability to understand the historical complexity of the Canary society from the first settlers up to the present. This incomprehension is rooted in some intellectual and ideologically driven groups, which wanted to show a cleansed and simplified version of the pre-Spaniard period, which is far from being real. It is open to doubt if the individuals that conform the informative system (owners, editors, journalist) are consciously endowing ideological or politically driven meanings to the mummies. However the editorial' trends, the economic control exerted by social and politically influential groups on most newspapers and the poor professional quality of the editors point out to an intentional use of the mummies with other purposes than mere informative.

It can be concluded from the language utilized and the poor investigative work done to contrast the informative sources that the Canary mass media is deficient in editors and journalists specialized in scientific reports. They neither investigate nor support with evidences their news about mummies. They just keep expectant to feed their reports with what the institutional communication department hand them in or what experts occasionally interviewed told them. As a result the information on the mummies is quite homogeneous and in line with official press releases and dossiers.

Mythic elements built up on the mummies by contemporary power-driven groups have occasionally displaced the scientific evidences.
The journalist' discourse takes advantage of any political, social or scientific polemic to create a "dramatic scene" that help to sell newspapers as happened when a scholar asserted that the aborigines could in theory have practiced some cannibalistic ritual in line with other aboriginal societies or the Archaeological museum acquired two mummies. The mass media sells news but also social pride, social identity illusions and ideology.

The archaeological museum considers mummies as most valuable aboriginal objects than others. In consequence it displays them in a prominent position and has backed any attempt to make them cultural symbols. The visitors, who are not able to solve the conflicting relation existing between the mummy as an object and a dead individual, somehow resist this determination. They are not quite clear about mummies being their ancestors or the symbols of a Canaries identity. In general the visitors eagerly accept the outstanding significance given to the mummies in the museum, because they are already pervaded with western conceptions about the material culture: antiquities from ancient cultures are more significant and valuable than other cultural elements. In opposition to the museum' endeavour to commoditize the mummies - otherwise natural to any western museum - the journalists persist in personifying them.

\section{Literature Cited}

Castell M. 2003. El poder de la identidad. Tomo 2, La era de la información: economía, sociedad y cultura. Alianza Editorial, Madrid.

Estévez González F. 1987. Indigenismo, raza y evolución. El pensamiento antropológico canario (1750-1900). Aula de Cultura de Tenerife-Museo Etnográfico, Santa Cruz de Tenerife.

García Morales M. 2003. Collecting the others, searching for ourselves. The biography of a collection of aboriginal objects. Ma Dissertation, Institute of Archaeology, UCL, London, (unpublished).

Meneses Fernández MåD. 2004.Aspectos de periodismo especializado: ciencia, cultura y canariedad en la prensa insular canaria.Años 1975 y 1982. Universidad de La Laguna, Servicio de Publicaciones.

Rodrigo Alsina M. 1999. "Las estrategias identitarias: entre el ser y el hacer". Revista Cidob d'Afers Internacionals, 43-44. Centro de investigación, docencia, documentación y divulgación de Relaciones Internacionales y Desarrollo. Institut Barcelona d'Estudis Internacional.Web page [accessed June, 2005]. Available at http://www.cidob.org/castellano/publicaciones/ Afers/43-44rodrigo.cfm 